\title{
THE IMPACT OF AIR QUALITY CONDITIONED BY EMISSION OF POLUTTANTS TO THE DEVELOPMENT OF RURAL TOURISM AND POTENTIALS OF RURAL AREAS
}

\section{Drago Cvijanović ${ }^{1}$,Jelena Matijašević - Obradovič́2, Sanja Škoričc ${ }^{3}$}

\begin{abstract}
Significant potentials for tourism development in Serbia are related to rural areas. Rural development, on its basis, includes the agrarian, but also the non-agrarian sector in rural areas, thus encompassing every vital component of the development of rural areas. This paper is, following the relevant theoretical positions, focused on key issues in the field of air quality impacts caused by the emission of pollutants to the development of rural tourism and the potentials of rural areas. These are primarily the following issues: which are the criteria for assessing air quality, or what are the limit values of the parameters for the protection of human health, and what is the trend of air quality by zones and agglomerations and what is the percentage of the population potentially exposed to concentrations of pollutants above the reference level. The mentioned topic is analyzed for the period 2012-2015. Analysis of the results of the degree of emission of suspended particles by zones and agglomerations in Serbia is presented correlatively in conclusion with concluding reviews on the existing ecological potential for the development of the basic rural areas in Serbia - Vojvodina, which makes up 28\% of the total area of Serbia, Central Serbia, which consists of $29 \%$ of the total area of Serbia and South Serbia, which accounts for 44\% of the total area of Serbia.
\end{abstract}

Key words: air quality, ecological potential, emission of suspended particles, rural tourism, sustainable rural development.

JEL: F64, L83, O13, O18, O44, Q19.

1 Drago Cvijanovic Ph.D., Full Professor, Principal Research Fellow, Dean of Faculty of Hotel Management and Tourism in Vrnjacka Banja University of Kragujevac, Vojvođanska street no. 5a, Vrnjačka Banja 36 210, Serbia, Phone: +381 63295 111; E-mail: drago.cvijanovic@kg.ac.rs; dvcmmv@gmail.com

2 Jelena Matijašević-Obradović Ph.D., Associate professor, Faculty of Law for Commerce and Judiciary in Novi Sad, Geri Karolja street no. 1, Novi Sad 21 000, Serbia, Phone: +381 60065 2249, E-mail: jela sup@yahoo.com

3 Sanja Škorić Ph.D., Assistant professor, Faculty of Law for Commerce and Judiciary in Novi Sad, Geri Karolja street no. 1, Novi Sad 21 000, Serbia, Phone: +381 638219788 , E-mail: sanja@pravni-fakultet.info

EP 2017 (64) 3 (871-885) 


\section{Introduction}

Rural tourism is tourism of rural areas, whose basic resource is natural and healthy environment.

Tourism is generally considered in scientific literature as an industry that has a significant effect on the economic, social and functional structure of rural areas and as an essential factor in the revitalization and diversification of rural economy (Ristić, Vujičić and Leković, 2016). Significant potentials for the development of tourism in Serbia are related to rural areas, where organic production of food with an authentic note of the area from which it is produced can be further initiated. Considering that , as many as $75 \%$ of the world's poor live in the rural areas and more than one-third of rural areas are in arid and semiarid regions" (Chaudhry, Gupta, 2010), one can certanly start with the attitude that „by introducing new non-agricultural activities (especially rural tourism), additional revenue can be generated and it would enable the improvement of quality of life and stop the demographic decline in rural areas"(Popesku, 2008). In this context rural tourism is identified as a tool for rural revitalization (Okech, Haghiri, George, 2012).

Rural areas in Serbia occupy about $85 \%$ of the territory inhabited by more than half of the total population (55\%), with a population density of 63 inhabitants per square kilometer (according to the $\mathrm{OECD}$, the area of up to 150 inhabitants per $\mathrm{km} 2$ is considered rural). In rural areas, most of the country's natural resources are located (agricultural land, forests, water) with its rich ecosystems and biodiversity. According to the Strategy of Agriculture and Rural Development of the Republic of Serbia for the period 2014-2024. (Official Gazette of the Republic of Serbia, No. 85/2014) the positive improvement made in previous years in organic production, wine production, products with geographical origin and agro tourism is emphasized.

Rural areas are interested to tourists, because rural areas, among other things, provide tourists a great opportunity for fun and entertainment. According to the geographic, economic, social, infrastructural and other trends, one can notice a high differentiation level of the Serbian rural areas (Cvijanović, Mihailović, 2016). According to the list drawn up by the Council of Europe, tourism activities in the rural area are numerous (Ružić, 2012). Namely, in the mentioned list, over 30 tourist activities, which are classified into 7 groups, can be noticed, such as: tours, water activities (rivers and lakes), air activities, sports activities, activities of work processes, culture activities and health character activities (Demonja, Ružić, 2010). The two main outcomes offered by rural tourism: farm hosting, in which country homes were used to provide hospitality, and farm holidays, during which the tourist was placed in rural areas and participated actively in the rural lifestyle that had been preserved as a primary agricultural activity (Corner, Swarbrooke, 2004). According to a market research consumers choose rural tourism for the following reasons: be in contact with nature, feel free, sunbathing, being outdoors, do unusual things, make an holiday to rest and be quiet (Ohe, 2000; Fagioli, Diotallevi, Ciani, 2014). The characteristics of visitors, which can easily be extended to matters concerning rural tourism are: love for nature, pleasure of genuine things, desire for peace, taste for the new, ability to adapt (Fagioli, Diotallevi, and 
Ciani, 2014). Finally, the rural area is interesting to tourists because it returns people from the urban environment to the nature, from where they originally belong (Ružić, 2012).

Rural development on its basis include the agrarian, but also the non-agrarian sector in rural areas, thus encompassing every vital component of the development of rural areas (economic, environmental, social, cultural, demographic, etc.).

An important factor for the impact on the development of rural tourism and rural areas in general is air quality, that is, the level of emissions of pollutants in certain regions.

In the context of this, this paper is, following the relevant theoretical positions, focused on the key issues in the field of air quality impacts caused by the emission of pollutants on the development of rural tourism and the potentials of rural areas, within the framework of the research work. These are primarily the following issues: which are the criteria for assessing air quality, or what are the limit values of the parameters for the protection of human health, and what is the trend of air quality by zones and agglomerations and what is the percentage of the population potentially exposed to concentrations of pollutants above the reference level. The mentioned topic is analyzed for the period 2012-2015.

\section{Literature review}

Tourism has frequently been launched as an alternative which potentially can contribute to more positive development that attracts visitors, in-migrants and investment, thus creating new employment and income opportunities in rural areas (Cawley, 2011; Halseth, Markey, Bruce, 2010; Asa, Lundmark, Pettersson, 2016). Rural tourism is one of the fastest spreading areas of tourism (Lopez and Garcia, 2006). In the literature, there is currently no uniform and universally accepted definition of rural tourism (Cvijanović, Vuković, 2016). Rural tourism is a common name for all forms of tourism, which can be realized in rural areas (Cvijanović, Radović, Cvijanović, 2016). Rural tourism is a growing sector and offers attractive growth opportunities that arise from the ability to respond to some of the emerging trends in tourism demand (Belletti, 2010). Rural tourism in Serbia is defined as tourism which offers a "rural environment" to the visitors by providing them experience of a unique connection of life of nature, culture and people. This implies that the visitor enjoys authentic, original experiences and returnment to the roots or essence of the rural way of life (Đorđević-Milošević, Milovanović, 2012). According to Fleischer and Pizam, rural tourism can be defined as a vacation, during which tourists use most of their free time to deal with recreational activities on the farm, ranch, country or its surroundings (Fleischer, Pizam, 1997). Rural tourism presents an important factor in the development and revitalization of rural areas. These areas are characterized by natural areas, which have their own characteristics: natural regions, anthropological achievements, construction styles in architecture, customs, traditions and languages (Hrabovski-Tomić, 2008). Rural tourism is referred to as an environmentally-oriented tourist product on the domestic and international tourist markets (Trukhachev, 2015). Also, rural tourism is expected to act as one of the tools for sustainable rural development (Ivolga, 2014). Middleton assumes that rural tourism is recognized as synonymous for the good life, which is reflected in the fresh air, spending time 
in the natural environment and life in harmony with nature and the community (Midlleton, 1982). Rural tourism is based on the principles of sustainability and includes a range of activities and services that the rural population is organizing precisely on the basis of the elements that characterize these rural areas (Đorđević-Milošević, Milovanović, 2012). Accordingly, rural tourism creates economic and social benefits for countryside, and it is an effective means of saving nature, culture and tradition values (Ališauskas, Jankauskiene, 2008). In addition, the offer in rural tourism does not only include visible characteristics of nature, architecture, folk creations, gastronomy, but also those invisible, such as, for example, traditional hospitality, customs, culture of relations with nature, culture of communication, beliefs and legends of the local population of different nationalities and religions that have developed a specific way of life in a specific area (Đorđević-Milošević, Milovanović, 2012). According to Pourova (2002), rural tourism as the tourism evolving both outside recreation and tourism centres and outside of urban areas (Pourova, 2002; Šimkova, 2007).

One of the important features of modern society is focus on sustainable development (Šimkova, 2007). Sustainable development, as a modern development concept that reconciles the social, economic and environmental interests of present and future generations, is very applicable in rural areas, which is confirmed both in theory and in practice, especially in developed countries (Ristić, 2013). Rural tourism and agritourism could lead a new relationship between environment, work and free time, in terms of sustainability of rural areas (Perotto, 1993; Fagioli, Diotallevi, Ciani, 2014). Hence, rural development is considered as a complex mesh of networks in which resources are mobilized and in which the control of the process consists of interplay between local and external forces (Lowe, Murdoch, Ward, 1995; Papić, Bogdanov, 2015). The following table shows the principles of rural development.

Table 1. Basic principles of rural development

\begin{tabular}{|c|c|c|c|}
\hline \multicolumn{4}{|c|}{ Sustainable rural development } \\
\hline $\begin{array}{l}\text { Environmental } \\
\text { principles }\end{array}$ & Social principles & $\begin{array}{l}\text { Cultural principles } \\
\text { (heritage) }\end{array}$ & $\begin{array}{l}\text { Economic } \\
\text { principles }\end{array}$ \\
\hline $\begin{array}{l}\text { - respect the natural } \\
\text { diversity of the } \\
\text { destination } \\
\text { - take measures to } \\
\text { control the carrying } \\
\text { capacity of the } \\
\text { destination along with } \\
\text { the development of } \\
\text { rural tourism }\end{array}$ & $\begin{array}{l}\text { - ensure that the } \\
\text { development of } \\
\text { tourism protects and } \\
\text { does not destroy } \\
\text { cultural diversity and } \\
\text { the local community } \\
\text { - actively discourage } \\
\text { the types of tourism } \\
\text { that cause and } \\
\text { contribute to social } \\
\text { problems }\end{array}$ & $\begin{array}{l}\text { - develop tourism that } \\
\text { is characteristic of the } \\
\text { area (native) - avoid } \\
\text { copying } \\
\text { - promote the unique } \\
\text { characteristics of the } \\
\text { culture and heritage of } \\
\text { the area }\end{array}$ & $\begin{array}{l}\text { - encourage } \\
\text { employment } \\
\text { opportunities to } \\
\text { prevent the outflow } \\
\text { of the population } \\
\text { - prevent the } \\
\text { disappearance } \\
\text { of traditional } \\
\text { occupations } \\
\text { - promote the use } \\
\text { and sale of local } \\
\text { food products }\end{array}$ \\
\hline
\end{tabular}

Source: Popesku (2011). 
It can be concluded that the sustainable development of rural tourism must be economically justified while preserving the natural, social and cultural characteristics of the tourist destination.

Namely, the versatile rural development implies demographic reconstruction, the use of available resources for the production of healthy food, the development of nonagricultural activities, urbanization in terms of infrastructure development, education, culture and preservation of the ecological environment. The concept of development of farm, small and medium enterprises, agro-production and agro-production, rural tourism, service activities of business cooperatives and advisory services is especially important (Veselinović, Ignjatijević, 2013).

\section{Methodology and data sources used}

The subject of the analysis in this paper are the key issues in the field of air quality impact caused by the emission of pollutants to the development of rural tourism and the potential of rural areas: criteria for assessing the quality of air, i.e. what are the limit values of parameters for the protection of human health, and what is the air quality trend by zones and agglomerations and how much percentage of the population is potentially exposed to concentrations of pollutants above the reference level. The survey will cover the four-year period - from 2012 to 2015.

In the theoretical part of the paper, the method of theoretical analysis of contents was primarily applied with the basic methods of concretization and specialization, while statistical and analytical-deductive methods were used in the research part of the paper, as well as the method of quantitative data analysis.

The research is based on official statistical data of Statistical Office of the Republic of Serbia.

\section{Research results and discussion}

In accordance with Article 5 of the Law on Air Protection (Official Gazette of RS, No. 36/2009 and 10/2013), the Decree on the Determination of Zones and Agglomerations (Official Gazette of the Republic of Serbia, Nos. 58/11 and 98/12) on the territory of the Republic of Serbia have been determined three zones and eight agglomerations (Popović et al., 2016; Popović et al., 2015; Popović et al., 2014; Popović et al., 2013):

- Zones: 1.) Zona „Serbia“, which includes the territory of the Republic of Serbia except the territories of the autonomous provinces, the city of Belgrade, the city of Niš, the city of Uzice, the city of Smederevo, the municipality of Kosjeric and the municipality of Bor; 2.) "Vojvodina" zone, which includes the territory of the Autonomous Province of Vojvodina except the territory of the cities of Novi Sad and Pancevo; 3.) The "Kosovo and Metohija" Zone, which includes the territory of the Autonomous Province of Kosovo and Metohija.

- Agglomerations: 1.) Agglomeration "Belgrade", which includes the territory of the 
city of Belgrade; 2.) Agglomeration "Novi Sad", which includes the territory of the city of Novi Sad; 3.) Agglomeration "Niš", which includes the territory of the city of Niš; 4.) "Bor" agglomeration, which includes the territory of the municipality of Bor; 5.) "Uzice" agglomeration, which includes the territory of the city of Uzice; 6.) "Kosjerić" agglomeration, which includes the territory of the municipality of Kosjerić; 7.) "Smederevo" agglomeration, which includes the territory of the city of Smederevo; 8.) The agglomeration "Pančevo", which includes the territory of the town of Pančevo.

The assessment of air quality based on the measured concentrations of pollutants in the air is carried out using the criteria for the assessment of air quality in accordance with the Regulation on conditions for monitoring and air quality requirements (Official Gazette of RS, No. 11/2010, 75/2010 and 63 / 2013) (Popović et al., 2016).

The following table presents the limit values of the parameters for the protection of human health, in accordance with the aforementioned regulation.

Table 2. Limits of parameters for the protection of human health

\begin{tabular}{|c|c|c|c|c|c|c|c|c|c|c|}
\hline 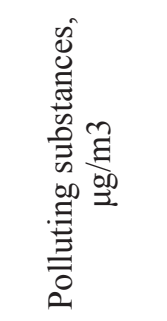 & 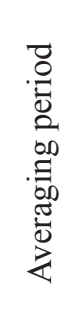 & 己. & 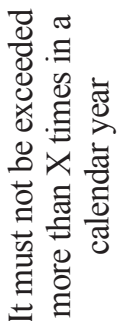 & 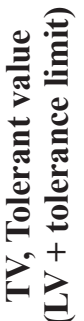 & $\frac{\text { ㄱ }}{\delta}$ & $\frac{\dot{r}}{\stackrel{\nu}{\sigma}}$ & $\frac{\dot{D}}{\stackrel{D}{\sigma}}$ & 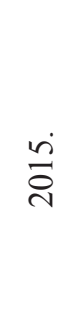 & 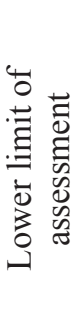 & 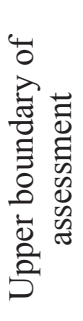 \\
\hline \multirow{3}{*}{$\begin{array}{l}\text { Sulfur } \\
\text { dioxide } \\
\left(\mathrm{SO}_{2}\right)\end{array}$} & $1 \mathrm{~h}$ & 350 & $24 x$ & 500 & 470 & 440 & 410 & 380 & - & - \\
\hline & $24 \mathrm{~h}$ & 125 & $3 x$ & 125 & & & & & 50 & 75 \\
\hline & 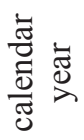 & 50 & - & 50 & & & & & - & - \\
\hline \multirow{3}{*}{$\begin{array}{c}\text { Nitrogen } \\
\text { dioxide } \\
\left(\mathrm{NO}_{2}\right)\end{array}$} & $1 \mathrm{~h}$ & 150 & $18 \mathrm{x}$ & 225 & 217,5 & 210 & 202,5 & 195 & 75 & 105 \\
\hline & $24 \mathrm{~h}$ & 85 & - & 125 & 121 & 117 & 113 & 109 & - & - \\
\hline & 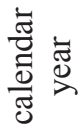 & 40 & - & 60 & 58 & 56 & 54 & 52 & 26 & 32 \\
\hline \multirow[b]{2}{*}{$\begin{array}{l}\text { Suspended } \\
\text { particles } \\
\text { PM }_{10}\end{array}$} & $24 \mathrm{~h}$ & 50 & $35 \mathrm{x}$ & 75 & 70 & 65 & 60 & 55 & 25 & 35 \\
\hline & 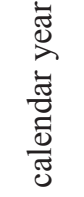 & 40 & - & 48 & 46,4 & 44,8 & 43,2 & 41,6 & 20 & 28 \\
\hline
\end{tabular}




\begin{tabular}{|c|c|c|c|c|c|c|c|c|c|c|}
\hline 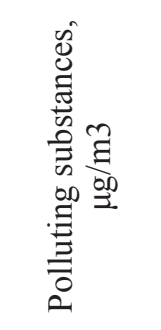 & 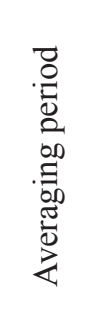 & 》. & 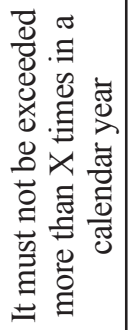 & 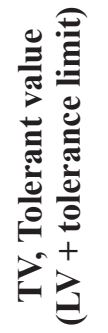 & 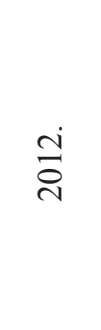 & $\stackrel{\dot{m}}{\stackrel{\sim}{\sigma}}$ & 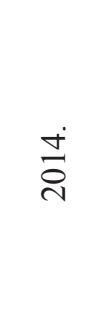 & $\stackrel{i}{\tilde{i}}$ & 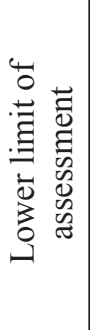 & 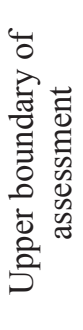 \\
\hline $\begin{array}{l}\text { Suspended } \\
\text { particles } \\
\mathrm{PM}_{2.5}\end{array}$ & 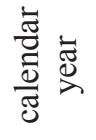 & 25 & - & 30 & 30 & 29,3 & 28,5 & 27,8 & 12,5 & 17,5 \\
\hline $\begin{array}{l}\text { Ozon } \\
\left(\mathrm{O}_{3}\right)\end{array}$ & $\begin{array}{c}8 \mathrm{~h} \\
\max \end{array}$ & 120 & $\begin{array}{c}25 \mathrm{x} \\
\text { in the } \\
\text { year for } \\
3 \text { years }\end{array}$ & & & & & & & \\
\hline \multirow{3}{*}{$\begin{array}{l}\text { Carbon } \\
\text { monoxide } \\
(\mathrm{CO})\end{array}$} & $\begin{array}{c}8 \mathrm{~h} \\
\max \end{array}$ & 10000 & - & 16000 & 14800 & 13600 & 12400 & 11200 & 5000 & 7000 \\
\hline & $24 \mathrm{~h}$ & 5000 & - & 10000 & 9000 & 8000 & 7000 & 6000 & - & - \\
\hline & 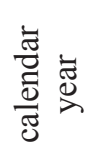 & 3000 & - & - & 3 & & & & & \\
\hline \multirow[b]{2}{*}{$\begin{array}{l}\text { Lead } \\
(\mathrm{Pb})\end{array}$} & $24 \mathrm{~h}$ & 1 & - & 1 & & & & & - & - \\
\hline & 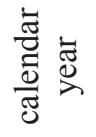 & 0,5 & - & 1 & 0,9 & 0,8 & 0,7 & 0,6 & 0,25 & 0,35 \\
\hline $\begin{array}{c}\text { Benzene } \\
\left(\mathrm{C}_{6} \mathrm{H}_{6}\right)\end{array}$ & 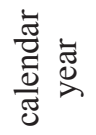 & 5 & - & 8 & 7 & 6,5 & 6 & 5,5 & 2 & \\
\hline
\end{tabular}

Source: Popović et al., (2016). Annual report on the air quality condition in the Republic of Serbia for 2015, Environmental Protection Agency, Belgrade, p. 13; Popović et al., (2015). Annual report on the air quality condition in the Republic of Serbia for 2014, Environmental Protection Agency, Belgrade, p. 18; Popović et al., (2014). Annual report on the air quality condition in the Republic of Serbia for 2013, Environmental Protection Agency, Belgrade, p. 19; Popović et al., (2013). Annual report on the air quality condition in the Republic of Serbia for 2012, Environmental Protection Agency, Belgrade, p. 13.

In accordance with the provisions of the Law on Air Protection, and according to the level of pollution, based on the prescribed limit and tolerance values, based on the results of the measurements, the following air quality categories are determined (Popović et al., 2016; 
Popović et al., 2015; Popović et al., 2014; Popović et al., 2013):

1.) the first category - pure or slightly polluted air where the limit values of the level for one pollutant are not exceeded;

2.) the second category - moderately polluted air where the level limit values for one or more pollutants are exceeded but tolerant values for one pollutant are not exceeded not for one pollutant;

3.) the third category - excessively polluted air where tolerant values for one or more pollutants are exceeded.

The following table shows the trend of air quality by zones and agglomerations, and in line with previously clarified air quality categories for the period 2012-2015.

Table 3. Trend of air quality by zones and agglomerations for the period 2012-2015.

\begin{tabular}{|c|c|c|c|c|c|c|}
\hline & & \multirow{2}{*}{ Population } & \multicolumn{4}{|c|}{ Categories of air quality } \\
\hline & & & 2012 & 2013 & 2014 & 2015 \\
\hline \multirow{5}{*}{ 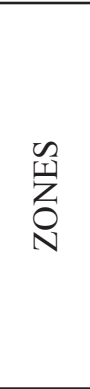 } & Serbia & $2,818,693$ & $\mathrm{I}$ & $\mathrm{I}$ & $\mathrm{I}$ & $\mathrm{I}$ \\
\hline & $\begin{array}{l}\text { The City of } \\
\text { Kragujevac }\end{array}$ & 179,417 & & & II & III \\
\hline & $\begin{array}{l}\text { The City of } \\
\text { Valjevo }\end{array}$ & 90,312 & III & III & III & III \\
\hline & \begin{tabular}{|l|} 
Vojvodina \\
\end{tabular} & $1,386,830$ & I & I & $\mathrm{I}$ & $\mathrm{I}$ \\
\hline & $\begin{array}{l}\text { The City } \\
\text { of Sremska } \\
\text { Mitrovica }\end{array}$ & 79,940 & & & II & III \\
\hline \multirow{8}{*}{ 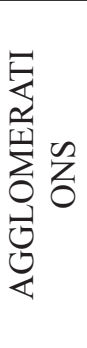 } & Novi Sad & 341,625 & $\mathrm{I}$ & $\mathrm{I}$ & I & II \\
\hline & Belgrade & $1,659,440$ & III & III & II & III \\
\hline & Pančevo & 123,414 & III & $\mathrm{I}$ & $\mathrm{I}$ & III \\
\hline & \begin{tabular}{|l|} 
Smederevo \\
\end{tabular} & 108,209 & III & III & III & \\
\hline & Bor & 48,615 & III & III & III & III \\
\hline & Kosjerić & 12,090 & III & II & $\mathrm{I}$ & \\
\hline & Užice & 78,040 & II & III & III & III \\
\hline & Niš & 260,237 & II & $\mathrm{I}$ & $\mathrm{I}$ & \\
\hline
\end{tabular}

Source: Popović et al., (2016). Annual report on the air quality condition in the Republic of Serbia for 2015, Environmental Protection Agency, Belgrade, p. 45; Popović et al., (2015). Annual report on the air quality condition in the Republic of Serbia for 2014, Environmental Protection Agency, Belgrade, p. 40; Popović et al., (2014). Annual report on the air quality condition in the Republic of Serbia for 2013, Environmental Protection Agency, Belgrade, p. 42.

By analyzing the data in Table 2, the limit values of the parameters for the protection of human health can be observed. Specifically, in accordance with Article 3 of the Regulation on the conditions for monitoring and air quality requirements (hereinafter: the Regulation), air quality requirements are, inter alia, the limit values of the levels of pollutants in the air; the upper and lower limits for assessing the level of pollutants in the air; the limits of tolerance and tolerance; concentrations dangerous to human health; 
critical levels of pollutants in the air, etc. Article 7 of the Regulation regulates that the level of air pollution is monitored by measuring the concentrations for sulfur dioxide, nitrogen dioxide and nitrogen oxides, suspended particles (PM10, PM2.5), lead, benzene, carbon monoxide, terrestrial ozone, arsenic, cadmium, nickel and benzo(a)pyrene in the air by instruments for automatic measurement and/or sampling and their analysis. Air quality monitoring is also carried out at the basic rural locations outside the direct impact of significant sources of air pollution to provide, as a minimum, information on the total mass concentration and the chemical composition of the suspended particles (PM2.5) based on the annual average (Article 9 of the Regulation). Boundary and tolerant values are the basis for: 1) air quality assessment; 2) division of zones and agglomerations into categories based on the level of air pollution; 3) air quality management (Article 15, paragraph 4 of the Regulation). In zones and agglomerations where the level of pollutants below the limit values is determined in Table 1, it is necessary to keep the concentrations of pollutants at a level below the limit values in order to preserve the best air quality in accordance with the principles of sustainable development. For polluting substances for which the tolerance limit is not prescribed, their threshold value is taken as tolerant value (Article 15, paragraphs 2 and 3 of the Regulation).

When there is sufficient data available, exceeding the upper and lower limits of assessment are determined based on the concentrations recorded over the past five years. The margin of appreciation is deemed to be exceeded if overtime has occurred during at least three of the mentioned five years (Prologue VII Section B of the Regulation).

By analyzing the data from Table 3, the following conclusions can be made. In the agglomeration "Novi Sad", the air was from 2012-2014. clean or slightly polluted, while in 2015 it transferred to the second category by pollution (moderately polluted), which indicates the growth trend of suspended particles in the last year shown. In the agglomeration "Belgrade", air was excessively polluted in 2012, 2013 and 2015, and was only moderately polluted in 2014, indicating a trend of decreasing the growth of suspended particles during 2014. In the Pancevo agglomeration, air was excessively polluted in 2012 and 2015, while in 2013 and 2014 it was clean or slightly polluted, which indicates a trend of significant reduction in the growth of suspended particles during the mentioned two years. In the agglomeration "Smederevo", air was polluted from 2012 to 2014, while in 2015 this agglomeration was not assessed. In the Bor agglomeration, the air was over-polluted in all four analyzed years, indicating a continuous emission trend and concentration of suspended particles in this area. In the Kosjeric agglomeration, air pollution was excessively polluted in 2012, moderately polluted in 2013, while air was either clean or slightly polluted in 2014, indicating a trend of decreasing the growth of suspended particles. In 2015, the agglomeration "Kosjerić" was not assessed In the "Užice" agglomeration, the air was moderately polluted in 2012, while in the period 20132015. it was excessively polluted, indicating a trend of increasing the growth of suspended particles in this area. In the agglomeration "Nis", the air was moderately polluted in 2012, while in 2013 and 2014 it was clean or slightly polluted, which indicates a trend of decreasing the growth of suspended particles in this area. In 2015, the agglomeration 
"Nis" has not been assessed.

If a review of the percentage of the population of the Republic of Serbia exposed to a different degree of air pollution in zones and agglomerations is made, the following conclusions can be drawn.

During 2015, 58.5\% of the population of the Republic of Serbia had clean or slightly polluted air. In the same period, $36.2 \%$ of the population had air quality that required improvement. In 2015, there was an increase in the percentage of the population in category III again (Popović et al., 2016). During 2014, 68.8\% of the population of the Republic of Serbia had clean or slightly polluted air. In the same period, $31.2 \%$ of the population had air quality that required improvement. In 2014, the percentage of population decreased in III, and increased in II category, which is a consequence of the transition of agglomeration Belgrade to the category of mild air pollution (Popović et al., 2015). In 2013, $28 \%$ of the population of the Republic of Serbia were potentially exposed to concentrations of pollutants above reference levels, above the limit and tolerant values (Popović et al., 2014). Observing the agglomerations in 2012, 74.16 population out of the total population in all eight agglomerations had air that belonged to category III after pollution.

\section{Conclusion}

Sustainable rural development depends on the practical application of the combination of the concept of multifunctional agriculture and the development of other economic activities in accordance with the available natural and human resources, the overall improvement of living conditions, as well as the socioeconomic position of villages and rural communities (Đorđević-Milošević, Milovanović, 2012). Certainly, air quality, as an important element of ecological capital, significantly influences the development of rural areas and rural tourism as activities that can greatly contribute to the development of the potential of rural areas.

Rural areas in Serbia are classified through a tripartite division, and include: 1.) the North Plains of Vojvodina, which makes up $28 \%$ of the total area of Serbia and $26 \%$ of its total population; 2.) Mountains and mountain regions of Central Serbia, which make up 29\% of the total area of Serbia with $44 \%$ of its population, and 3.) The mountains and valleys of South Serbia, which account for $44 \%$ of the total area of Serbia (Đorđević-Milošević, Milovanović, 2012). If we look at the presented data for eight agglomerations in Serbia, classified in three categories, according to the degree of air pollution to agglomerations with clean or slightly polluted air, agglomerations with moderately polluted air, and agglomerations with excessively polluted air, we can realize that the percentage of suspended pollutant particles varied in agglomerations by years (2012-2015), and that the data indicate the following conclusions:

- agglomeration "Novi Sad" can be classified in a group of areas with mostly clean or slightly polluted air (in the period from 2012-2014, the air was clean or slightly polluted, while in 2015 it was transferred to another category by pollution - moderately polluted 
air), which, from the aspect of air quality, is a significant potential for the development of rural areas in this part of Serbia;

- agglomerations "Pancevo", "Kosjeric" and "Nis" can be classified in a group of areas with mostly moderately polluted air (in the agglomeration "Pancevo", the air was excessively polluted in 2012 and 2015, while in 2013 and 2014, air was clean or slightly polluted; in the Kosjeric agglomeration, air pollution was excessively polluted in 2012 , moderately polluted in 2013, while in 2014 air was clean or slightly polluted. In 2015, the Kosjerić agglomeration was not assessed; In the agglomeration "Nis", the air was moderately polluted in 2012, while in 2013 and 2014 it was clean or slightly polluted. In 2015, the agglomeration Nis was not evaluated), which, from the aspect of air quality in these areas, is a solid potential for the development of rural areas in this part of Serbia, which still requires further improvements in further rural development;

- agglomerations "Smederevo", "Bor", "Belgrade" and "Uzice" can be classified in a group of areas with predominantly excessively polluted air (in agglomeration "Bor", air was polluted over all four years analyzed; in agglomeration "Smederevo", the air was polluted from 2012 to 2014, while in 2015 this agglomeration was not assessed; in the agglomeration "Belgrade ", the air was polluted in 2012, 2013 and 2015, and was only moderately polluted in 2014, while in the "Uzice" agglomeration, the air was moderately polluted in 2012, while in the period 2013 -2015 was over-polluted) which, observed from the aspect of air quality, is a factor that does not stimulate the development of rural areas in this part of Serbia, and in these agglomerations it is necessary to introduce a series of changes and improvements that will lead to a reduction in pollutant emissions, and enable better ecological potential in further stages of rural development.

\section{Literature}

1. Ališauskas, K., Jankauskiene, A. (2008): Kaimo pletros tendencijos Plunges rajone, Ekonomika ir vaduba: aktualijos ir perspektyvos, Vol. 2, No. 11, pp. 34-43, Šiauliu universitetas, Lietuva.

2. Asa, A., Lundmark, L., Pettersson, O. (2016): Public spending on rural tourism in Sweden, Fennia, Vol. 194, No. 1, pp. 18-31, Geographical Society of Finland, Finland.

3. Belletti, G. (2010): Ruralità e Turismo, Agriregionieuropa, Vol. 6, No. 20, Associazione "Alessandro Bartola", Ancona.

4. Cawley, M. (2011): Adding value locally through integrated rural tourism: lessons from Ireland, Proceedings from the conference-The next rural economies: constructing rural place in global economies, Wallingford, England, pp. 89-101.

5. Chaudhry, P., Gupta, R. K. (2010): Urban greenery and its sustainable extension strategies in hot arid region of India. International Journal of Sustainable Society, Vol. 2, No. 2, pp. 146-155, Inderscience Publishers, United Kingdom.

6. Corner, S., Swarbrooke, J. (2004): International Cases in Tourism Management, Butterworth-Heinemann, Oxford, United Kingdom.

7. Cvijanović, D., Mihailović, B. (2016): Developmental aspects of the Rural Tourism 
in Serbia, Proceedings from the conference - Tourism in function of Development of the Republic of Serbia - Spa Tourism in Serbia and Experiences of Other Countries, Vrnjačka Banja, The Republic of Serbia, pp. 1-16.

8. Cvijanović, D., Radović, G., Cvijanović, G. (2016): Resources and the Rural Tourism Development in the Republic of Serbia, Proceedings from the conference - Horizons, Bitola, The Republic of Macedonia, Vol. 20, pp. 41-52.

9. Cvijanović, D., Vuković, P. (2016): Perspectives of Sustainable Tourism Development of Smederevo, Agricultural Bulletin of Stavropol Region, Vol. 24, No. 4, pp. 14-16, Stavropol State Agrarian University, Stavropol, Russia.

10. Demonja, D., Ružić, P. (2010): Ruralni turizam u Hrvatskoj s primjerima dobre prakse i europskim iskustvima, Meridijani Samobor, Zagreb, Republika Hrvatska.

11. Đorđević Milošević S., Milovanović J. (2012): Održivi turizam u funkciji ruralnog razvoja - Mala poljoprivredna gazdinstva i ruralni turizam u Srbiji, Fakultet za primenjenu ekologiju Futura Univerziteta Singidunum, Beograd, Republika Srbija; Agroznanje, Vršac, Republika Srbija; FAO, Budimpešta, Republika Mađarska.

12. Fagioli, F. F., Diotallevi, F., Ciani, A. (2014): Strengthening the sustainability of rural areas: the role of rural tourism and agritourism, Rivista di Economia Agraria, Vol. 69, No. 2-3, pp. 155-169, Firenze University Press, Firenze, Italia.

13. Fleischer, A., Pizam, A. (1997): Rural tourism in Israel, Tourism Management, Vol. 18, No. 6, pp. 367-372, Elsevier, Amsterdam, The Nederlands.

14. Halseth, G., Markey, S., Bruce, D. (2010): The next rural economies: constructing rural place in global economies, CABI Publishing, Wallingford, England.

15. Hrabovski Tomić, E. (2008): Selektivni oblici turizma, Fakultet za uslužni biznis, Sremska Kamenica, Republika Srbija.

16. Ivolga, A. (2014): Overview of contemporary issues of sustainable rural development in Russia in terms of existing differences between regions, Economics of Agriculture, Vol. 61, No. 2, pp. 331-345, Institute of Agricultural Economics, Belgrade, The Republic of Serbia.

17. Lopez, E. P., Garcia, F. J. C. (2006): Agrotourism, Sustainable Tourism and Ultraperipherial Areas: The Case of Canary Islands, PASOS - Revista de Turismo y Patrimonio Cultural, Vol. 4, No. 1, pp. 85-97, The Institute for Social and Tourism Research of University of La Laguna and The University Institute of Maia-ISMAI, Islas Canarias, Spain.

18. Lowe, P., Murdoch, J., Ward, N. (1995): Networks in rural development beyond exogenous and endogenous models, in Book - Beyond modernization: The impact of endogenous rural development, Vol. 1, pp. 87-106, Van Gorcum, Assen, Netherlands.

19. Midlleton, T.C.V. (1982): Tourism in rural areas, Tourism Management, Vol. 3, No. 1, pp. 52-58, Elsevier, Amsterdam, The Nederlands.

20. Okech, R., Haghiri, M., George, P. B. (2012): Rural tourism as a sustainable development alternative: an analysis with special reference to Luanda, Kenya, Cultur, 
Vol. 6, No. 3, pp. 36-54, Universidade Estadual de santa Cruz, Brasil.

21. Ohe, Y. (2000): On-farm Tourism Activity and Attitudes of the Operators: A HiroshimaUmbria Comparative Case Study, The Technical Bulletin of Faculty of Horticulture, Vol. 54, pp. 73-80, Chiba University, Japan.

22. Papić, R., Bogdanov, N. (2015): Rural Development Policy - a perspective of local actors in Serbia, Economics of Agriculture, Vol. 62, No. 4, pp. 1079-1093, Institute of Agricultural Economics, Belgrade, The Republic of Serbia.

23. Perotto P.G. (1993): Il paradosso dell'economia; Manuale di rivoluzione cultural, Franco Angeli, Milano, Italia.

24. Popesku, J. (2008): Održivi turizam, u Brošuri - Ruralni razvoj i ruralni turizam, pp. 9-13, Agromreža, Novi Sad, Republika Srbija.

25. Popesku, J. (2011): Sustainable development of rural tourism, Taiex, Chamber of Commerce, Belgrade, The Republic of Serbia, (available at: http://www.kombeg.org. rs/Slike/UdrTurizam/2011/novembar/TAIEX/Prezentacije/Beograd.pdf).

26. Popović, T., Knežević, J., Jović, B., Marić-Tanasković, L., Dimić, B. (2016): Annual report on the air quality condition in the Republic of Serbia for 2015, Environmental Protection Agency, Ministry of Agriculture and Environmental Protection, Belgrade, The Republic of Serbia.

27. Popović, T., Jović, B., Marić-Tanasković, L., Knežević, J., Dimić, B. (2015): Annual report on the air quality condition in the Republic of Serbia for 2014, Environmental Protection Agency, Ministry of Agriculture and Environmental Protection, Belgrade, The Republic of Serbia.

28. Popović, T., Jović, B., Marić-Tanasković, L., Knežević, J., Mitrović Josipović, M., Dimić, B. (2014): Annual report on the air quality condition in the Republic of Serbia for 2013, Environmental Protection Agency, Ministry of Agriculture and Environmental Protection, Belgrade, The Republic of Serbia.

29. Popović, T., Jović, B., Marić-Tanasković, L., Knežević, J., Đorđević, D., Dimić, B. (2013): Annual report on the air quality condition in the Republic of Serbia for 2012, Environmental Protection Agency, Ministry of Agriculture and Environmental Protection, Belgrade, The Republic of Serbia.

30. Pourová, M. (2002): Agroturistika, Credit, Prague, Czech Republic.

31. Regulation on determining zones and agglomerations, Official Gazette, The Republic of Serbia, No. 58/2011 and 98/2012.

32. Regulation on monitoring conditions and air quality requirements, Official Gazette, The Republic of Serbia, No. 11/2010, 75/2010 and 63/2013.

33. Ristić, L. (2013): Strazegijsko upravljanje održivim ruralnim razvojem u Republici Srbiji, Ekonomski horizonti, Vol. 15, No. 3, pp. 229-243, Ekonomski fakultet Univerziteta u Kragujevcu, Kragujevac, Republika Srbija.

34. Ristić, L., Vujičić, M., Leković, M. (2016): Tourism as a factor of Ssustainable Development of rural areas belonging to Rudnička Morava, Economics of Agriculture, 
Vol. 63, No. 2, pp. 665-680, Institute of Agricultural Economics, Belgrade, The Republic of Serbia.

35. Ružić, P. (2012): Analiza posebnosti i percepcije ruralnog turizma Istre, Ekonomska misao i praksa, Vol. 21, No. 1, pp. 217-238, Univerzitet u Dubrovniku, Dubrovnik, Republika Hrvatska.

36. Strategija poljoprivrede i ruralnog razvoja Republike Srbije za period 2014-2024. godine, Službeni glasnik, Republika Srbija, no. 85/2014.

37. Šimkova,E.(2007): Strategic approaches to rural tourism and sustainable development of rural areas, Agricultural Economics, Vol. 53, No. 6, pp. 263-270, Czech Academy of Agricultural Sciences, Prague, Czech Republic.

38. The Law on Air Protection, Official Gazette, The Republic of Serbia, No. 36/2009 and 10/2013.

39. Trukhachev, A. (2015): Methodology for Evaluating the Rural Tourism Potentials: A Tool to Ensure Sustainable Development of Rural Settlements, Sustainability, Vol. 7, No. 3, pp. 3052-3070, MDPI Publishing Services, Basel, Switzerland.

40. Veselinović, J., Ignjatijević, S. (2013): Pravni okvir i ekonomske mere za unapređenje agroturizma, Zbornik radova sa konferencije - Planska i normativna zaštita prostora i životne sredine, Subotica - Palić, Republika Srbija, pp. 145-150. 


\title{
UTICAJ KVALITETA VAZDUHA USLOVLJENOG EMISIJOM ZAGAĐUJUĆIH MATERIJA NA RAZVOJ RURALNOG TURIZMA I POTENCIJALA RURALNIH PODRUČJA
}

\author{
Drago Cvijanovič́, Jelena Matijaševićc - Obradovič ${ }^{5}$, Sanja Škorić ${ }^{6}$
}

\begin{abstract}
Apstrakt
Značajni potencijali za razvoj turizma u Srbiji tiču se upravo ruralnih područja. Ruralni razvoj u svojoj osnovi obuhvata agrarni, ali i neagrarni sektor u ruralnim područjima, te time obuhvata svaku vitalnu komponentu razvoja ruralnih područja. U radu je nakon relevantnih teorijskih stavova, pažnja usmerena na ključna pitanja u oblasti uticaja kvaliteta vazduha uslovljenog emisijom zagađujućih materija na razvoj ruralnog turizma i potencijala ruralnih područja. To su prevashodno sledeća pitanja: koji su kriterijumi za ocenjivanje kvaliteta vazduha, odnosno šta su i kolike su granične vrednosti parametara za zaštitu zdravlja ljudi, te kakav je trend kvaliteta vazduha po zonama i aglomeracijama i koliki je procenat stanovništva potencijalno izložen koncentracijama zagađujućih materija iznad referentnog nivoa. Pomenuta tematika analizirana je za period 2012.-2015. godina. Analiza rezultata o stepenu emisije suspendovanih čestica po zonama $i$ aglomeracijama u Srbiji, u zaključku je korelativno predstavljena sa zaključnim osvrtima na postojeći ekološki potencijal za razvoj osnovnih ruralnih oblasti u Srbiji - Vojvodine, koja čini $28 \%$ ukupne površine Srbije, Centralne Srbije, koji čine 29\% ukupne površine Srbije i Južne Srbije, koja čini 44\% ukupne površine Srbije.
\end{abstract}

Ključne reči: kvalitet vazduha, ekološki potencijal, emisija suspendovanih čestica, ruralni turizam, održivi ruralni razvoj.

4 Redovni profesor, dr Drago Cvijanović, Dekan Fakulteta za hotelijerstvo i turizam u Vrnjačkoj Banji, Univerzitet u Kragujevcu, Vojvođanska ulica br. 5a, 36210 Vrnjačka Banja, Srbija, Telefon: +381 63295 111; E-mail: drago.cvijanovic@kg.ac.rs; dvcmmv@gmail.com

5 Vanredni profesor, dr Jelena Matijašević-Obradović, Pravni fakultet za privredu i pravosuđe u Novom Sadu, Ulica Geri Karolja br. 1, Novi Sad, Srbija, Telefon: +381 60065 2249, E-mail: jela_sup@yahoo.com.

6 Docent, dr Sanja Škorić, Pravni fakultet za privredu i pravosuđe u Novom Sadu, Ulica Geri Karolja br. 1, Novi Sad, Srbija, Telefon: +381 638219 788, E-mail: sanja@pravni-fakultet.info. 